\title{
Smooth Muscle IgG Antibody Measurement
}

National Cancer Institute

\section{Source}

National Cancer Institute. Smooth Muscle IgG Antibody Measurement. NCI Thesaurus.

Code C122151.

The determination of the amount of smooth muscle IgG antibody present in a sample. 